DOI: 10.20472/IAC.2018.039.032

JESSICA MURRAY

UNISA, South Africa

\title{
THE ROLE OF SHAME IN THE CONSTRUCTION OF VICTIM NARRATIVES: A FEMINIST LITERARY ANALYSIS OF ANTJIE KROG'S OEUVRE.
}

\begin{abstract}
:
This paper will explore a relatively under researched aspect of victim narratives, namely the role that shame in general, and gendered shame in particular, plays in the construction of these narratives. Although Antjie Krog's Country of my Skull has received wide local and international attention, the dynamics of shame demand further scholarly attention. I will offer a feminist literary analysis of Krog's text, in addition to her A Change of Tongue, Begging to be Black and There was this Goat (co-written by Nosisi Mpolweni and Kopano Ratele), through a theoretical rubric of shame studies. In the South African context, victim narratives have become part of the public consciousness through the post-apartheid Truth and Reconciliation Commission Hearings. In the contemporary South African milieu, the gendered and racialized female body is more susceptible to violence than ever before and the emergent victim narratives of women thus deserve additional scholarly scrutiny. It has become a widely accepted reality that gender violence remains severely underreported and women's victim narratives are thus particularly vulnerable to silencing and elision from public discourses. The very nature of shame, with its impulse to shrink, hide and remain silent, makes this a phenomenon that shapes victim narratives in particularly insidious ways. In order to expose the dynamics of shame and their effects on the construction of victim narratives, I turn to literary texts as these provide a safe space from which to explore issues that are often immensely painful and traumatizing to the women who have been victimized. The prevalence of sexual violence in South Africa, with some of the highest rates of rape in the world, results in fiction writers often attempting to utilize the imaginative space of literary texts to grapple with this uncomfortable social reality. As a feminist scholar, I argue that these texts offer valuable analytical opportunities and I will explore Krog's oeuvre in order to ascertain the role that shame plays in the construction of South African victim narratives. My analysis will demonstrate that assumptions about "proper" feminine traits and behaviour are so deeply embedded that shame about perceived deviation from these normative standards goes to the very heart of the construction of victim narratives by both the female characters themselves and the larger societies in which they are located.
\end{abstract}

\section{Keywords:}

shame, victim narratives, gender, Antjie Krog 
In arguably Krog's most important text to date, Country of my Skull, one of her chapters is entitled "Truth is a Woman". In this chapter, she focuses her analytical gaze on the gendered nature of the violence that was perpetrated by the apartheid regime and I quote the following extract at length because it so succinctly reveals the gendered role of shame in women's experiences of violence. The narrator of this extract is Thenjiwe Mthintso who was the chairperson of the Gender Commission at the time.

'Behind every woman's encounter with the Security Branch and the police lurked the possibility of sexual abuse and rape.' Some activists say they sometimes didn't know which was worse - the actual assault or dealing with the constant fear in the confined and isolated space of a cell. 'When they interrogated, they usually started by reducing your role as an activist. They weighed you according to their own concepts of womanhood. 'And they said you are in custody because you are not the right kind of woman - you are irresponsible, you are a whore, you are fat and ugly, or single and thirty and looking for a man (Krog, 1998: 178-179).

Being assessed according to prevailing ideals of womanhood and being found wanting lie at the core of gendered shaming and these dynamics make the narratives of female victims of violence substantively different from those of male victims. I am, of course, not suggesting that men do not experience shame, but my argument here is that shaming is fundamentally gendered and this article explores women's experiences of shame. In her important work on shame, Cathrine Norberg (2012:161) notes how "shame may be seen as a reflection of societal pressures placed on women to conform to certain standards of femininity..." and how shame can function as a disciplinary mechanism to remind women of the need to maintain a "perpetual adjustment to stereotypical feminine traits". In the extract above, being "the right kind of woman" according to apartheid era Afrikaner patriarchal norms, involved being sexually chaste, married and conforming to particular ideals of beauty. By focusing on the female detainees' failure to adhere to these norms, the police officers are consciously erasing their work as political activists and putting them back in their "rightful" place as women. After invalidating their political contribution to liberation, they then use shame to deny their identity as women. Norberg (2012: 162) also reminds us that "a woman's shame is typically presented as sexually coded". Kaye Mitchell (2012: 5) in turn, cautions scholars to be wary of the "extent to which the continuing association of sexual shame with the female body tends to be elided or overlooked in recent queer [and, I would add, feminist] theoretical considerations of shame" [emphasis in original]. While feminist theoretical interventions in the intersections of gender, shame and the female body have certainly made great strides over the course of the past six years, this was very much an under researched area when the bulk of academic analyses of Country of my Skull was produced. These considerations have prompted me to return to extracts from Krog's text, such as the one below, since more contemporary feminist studies on shame illuminate it in new ways. Like the one above, this extract refers to the experiences of female detainees during apartheid. 
Then things happened that could not happen to a man. Your sexuality was used to strip away your dignity, to undermine your sense of self. You had to ask for toiletries like deodorant, soap and sanitary towels. You had to strip in front of a whole range of policemen making remarks about your body. Women had to do star-jumps naked, breasts flying, Fallopian tubes were flooded with water until they burst, rats were pushed into vaginas ... Women have been made to stand the whole day with [menstrual] blood flowing down and drying on their legs (Krog, 1998: 179).

Mthintso wonders what the rationale for these clearly gendered tactics were as she asks "Did they [the interrogators] gain strength from looking at their [the female detainees'] blood"? (179). My contention in this article is that the rationale can be traced back to what Mitchell (2012: 1) refers to as the "continuing imbrication of femininity and shame". The invocation of female shame in the context of the extract makes sense when we take cognisance of the "political work that shame does" (Mitchell, 2012: 2). It works politically by reinforcing the gendered status quo of normative femininity and, more specifically, it functions politically here to break down the resistance of the woman who is being interrogated.

Even though the narrator does not use the word "shame", the dynamics of shame are undeniably at play here. Mthintso notes that she still feels "unready ... to talk about [her] experience in South African jails and ANC camps abroad" and that she still feels "exposed and distraught" (Krog, 1998: 179). Once again, the description points to the presence of shame even without explicitly naming it as such. In her ground breaking work on shame, Elspeth Probyn (2005: 2) argues as follows: "Shame makes us feel small and somehow undone. It's no wonder that in most societies, shame tends not to be talked about, let alone vaunted". Like other scholars, she draws a clear distinction between guilt and shame and of the ways in which they differ is that "[g]uilt is easier to get rid of and once dealt with is forgotten, whereas shame lingers deep within the self" (2). Frank Davidoff (2002: 623) similarly finds that "shame is so devastating because it goes right to the core of a person's identity, making them feel exposed, inferior, degraded; it leads to avoidance, to silence".

This shrinking impulse that is associated with shame can help us to understand why female victims of apartheid violence were so reluctant to structure their Truth and Reconciliation Commission narratives around their own experiences. The text repeatedly refers to female testifiers' silences and physical shrinking or a protective closing in on the self. For instance, when Rita Mazibuko "leaves the witness table she pulls her cardigan closed and folds her arms protectively over her body" (184). Interestingly, while one has to read between the lines to detect the shame shaping the narratives of the women in the text, the term is explicitly used to describe the feelings of an anonymous Afrikaans letter writer who wonders "how it is possible that often I also just looked on. Then I wonder how it is possible to live with this inner guilt and shame..." (46-47). Even in this instance, the use of the term "shame" is questionable as it is offered as a direct translation of "skuld en skande" where the latter could also plausibly be 
translated as "scandal" rather than as "shame". The term again appears in Country of my Skull as a subheading that reads "Shame strangles the remembrance of you" [italics in original] (73). The section that follows deals with the testimony of male perpetrators and victims.

The function of sexualised shame as a tool of silencing and gendered discipline with a focus on the bodies of the women being shamed also emerges when one reads the experiences of the semi fictionalised narrator, Antjie Krog, herself. Due to her attempts to be part of the reconciliation process, she is regarded as the ultimate deviation from "proper" and accepted Afrikaner womanhood and men use threats of violence and explicitly sexualised language to try to put her in her gendered place. She recalls a telephone call where someone threatens her as follows: "We're coming for you tonight. A traitor and slut like you must be shot like a dog" (90). Her supposed treachery is linked to her engagements with the African National Congress but, interestingly, the caller invokes the shame of sexual promiscuity to dehumanise her and rationalise his threat to kill her like an animal. As with Mthintso above, the spectre of shame works to elide her actual political work and to paint her as a failed woman because that, the implication is, constitutes the most egregious transgression of all. In addition to the shaming she receives from racist Afrikaners, Krog struggles with the shame of herself being an Afrikaner who benefited from the atrocities of apartheid violence. In one of the text's many harrowing sections, she describes an incident where we can read the political use of sexualised shame between the lines and this is followed by her explicit use of the term "shame" in relation to her own feelings about the incident. The TRC commissioners go to a place where a perpetrator reveals where they buried a woman they killed after interrogation. When the digging reveals "the earth holding a bundle of bones", the following description is offered: "Around the pelvis is a blue plastic bag. 'Oh yes.' The grave indicator [and perpetrator] remembers. 'We kept her naked and after ten days she made herself these panties.' He sniggers: 'God ... she was brave'” (128). When they could not get any information out of this female detainee, they shot her, but not before using her nakedness as part of an effort to break her down. Even though she "simply would not talk" (128), the underwear made from a plastic bag suggests that, amid what must have been horrific torture and physical pain, the perpetrators strategy of shaming her naked body bothered her so much that she tried to cover herself up with whatever disposable item she could find. After all this time, the torturer's recollection of this fact with his "snigger" suggests that he knows that, even though they got no information from her, some part of their strategy was effective. Probyn's (2005: 79) reflections on both the gendered nature of shame and the intersections of individual shame and the broader politicization thereof become relevant to this analysis when she reminds us that "shame is a powerful instance of embodiment, but it is also called into being by, and then inflects, historical and political circumstances". She continues to note that shame "is felt at different levels in individual bodies and in the body politic" (Probyn, 2005: 79). It is in this section of text that Krog uses the term "shame" to consider how to engage with apartheid as a white Afrikaans woman. She repeatedly evokes images of silence in the to suggest the challenges that arise when attempting to move forward from this place 
of violence: "Speechless I stand before the Archbishop. Whence will words now come? For us. We who hang quivering and ill from this soundless space of Afrikaner past? What does one say? What the hell does one do with this load of decrowned skeletons, origins, shame and ash?" (128).

In 2009, more than a decade after the publication of Country of my Skull, Krog published Begging to be Black in which she explores her implication in a murder in her home town of Kroonstad. Although these are very different texts, Krog utilises some of the same techniques, such as the fictionalisation of historical events and the explicit location of herself in the narrative, to continue her consideration of some of the same issues that were raised in Country of my Skull. She is particularly concerned with her role in the post-apartheid narrative and in the possibility of moving forward in a profoundly wounded country. Although formal apartheid has been abolished, contemporary socioeconomic realities mean that the very notion of South Africa as a post-apartheid society is a problematic one. Krog (2009: 159) writes that every single thing in our country already portrays injustice, reminds us of the ongoing injustice. One need not pull it out of the past through plaques and memorials; it is walking around, mortally wounded, poor or corrupted, the victims and the perpetrators. The shame belongs to a colour - that colour is a reminder.

Krog is reflecting on the South African situation while she is in Berlin and she is stunned by the city's numerous physical memorials that "are found right across the city, marking the names of the disappeared, daily confronting the neighbours who claimed they hadn't noticed" (158). The presence of shame again emerges when she offers the following recollection of her trip to Germany:

I found a book about the Second World War in which a woman wrote that, after she had finished her shopping at the corner shop, she came across a long queue of Jewish people walking in the streaming rain through the city towards the Grunewald station [which was near the place where Krog's fictionalised narrator stays during her visit to Germany]: 'Quite a long queue it was. The people on the streets who saw them were actually ashamed'.

The notion of feeling shame because of the injustices that were committed in one's name emerges repeatedly and explicitly in the text but, for the purposes of this article, it is also important to note how Krog's fictionalised narrator engages with this shame from within a fundamentally gendered body. The references to the narrator's gendered identity appear to be tangential to the main events of the plot but, I would argue, they remain crucial to a holistic reading of the text. Krog first gained public attention and literary accolades as a poet and her poetic training means that, as an author, she knows that every word matters. Her inclusion of references to specifically gendered experiences, even as she is describing so-called big political issues such as murder, holocaust memorialisation and post-apartheid reconciliation, thus matters, and the tendency of scholars to rush past these sections, or to ignore them altogether, is a 
serious analytical oversight that impoverishes the reading of the text as a whole. Krog's narrator locates herself within the text as a white, Afrikaans woman and, in a number of highly self-reflexive passages, she explores how this identity is used by members of her larger communities to put her back into her proper gendered place when she dares to challenge the political status quo. This is done with various degrees of nuance and subtlety, or lack thereof, but the gendered dynamics of these interactions always provide feminist scholars with important information. Within the first ten pages of the text, for instance, the narrator reports an act of vandalism to the local police station and her reception is related as follows:

At the police station they ignored me. After some minutes I tried to address a policeman who was just sitting there staring at me. 'Haai meneer? [hey mister?]

Without taking his eyes off me, he shouted to the back, 'She's here.' To which somebody replied, 'Hope she's not looking for police protection!' Sniggering all around. [...]

'Sorry, mevroutjie,' [diminutive of Mrs] he said cheerfully, 'we can't do anything - there was an AWB [Afrikaners Weerstandsbeweging] meeting in Kroonstad last night.' (Krog, 2009: 7)

A number of things are happening in this brief extract and their cumulative function is to remind the narrator that she is profoundly vulnerable in her female body. The policeman's tactic of staring at her while ignoring her serves to render her simultaneously hyper visible and completely powerless. This is reinforced when he notes that "she" is there. The use of the nameless pronoun makes it clear that they have been discussing and expecting her but they snigger to confirm that the idea of her seeking the protection of the police is a completely ridiculous one. She is on her own even though her personal property has been attacked. By using the diminutive form of the Afrikaans version of missus, the policeman firmly puts her in her gendered place and his cheerful tone suggests his glee at being able to play this trump card. Later in the text, allegations of sexual promiscuity are levelled at her to impugn her character when her husband tells her that "the town is humming with gossip", including "that Reggie and [she] are lovers..." (42). Once again, the implication is that, since she fails to conform to the image of a good Afrikaans woman, she is shamed and thus rendered powerless as a political agent in her small rural town of Kroonstad.

The ubiquity and persistence of patriarchal oppression, albeit in different forms, also emerge at the other end of the political spectrum when the narrator recounts an experience at an ANC [African National Congress] rally. She recalls how the "comrades asked [her] to help the women prepare a lunch..." (Krog, 2009: 14) that would be held for an ANC dignitary after the rally. She notes that "[t]his meant [she] had to miss the rally, in order to take care of things at home where the man would eat" and, even though she "protested", her function and that of the other women at the political event is described as follows: ".. we dished up, poured cooldrinks, cleared away, refilled plates, 
washed up - in our places, we little women" (14). Her use of the adjective "little" here echoes the diminutive form of Mrs that the policeman used above and it suggests that she finds both these instances similarly troubling.

The centrality of the female body, and the way female embodiment is used as an instrument of oppression against women, is clear in another, seemingly tangential, section of the text. In another confrontation with a policeman, the narrator is startled by the following memory:

And it jumps up at me, something I have forgotten, deliberately forgotten: the day my daughter phoned from boarding school in Bloemfontein - it was a few months after I had been told that our phone had been tapped. She sounded as I had not heard her sound before. 'I have started to menstruate.' She spoke with the thrill of threshold, with the shock that comes from seeing blood spill from your body, not from harm or hurt, but from becoming closer to what you are. I went ice cold. The knowledge of the hairy police ear eavesdropping on this most private of all moments between a mother and her daughter immobilized me into stone. I cannot remember what I said, only that I have been haunted for the rest of my life by my inadequacy to break through their malice in order to embrace my child (37).

I quote this passage at length because it offers such a trove of insights to a feminist scholar who is reading the text with a focus on the gendered utilisation of shame as an instrument of disempowerment. The narrator's daughter and their relationship do nothing to forward a complex plot that deals with a murder, colonialism and apartheid, yet Krog chooses to include this description. Our first hint that we need to pay attention is the admission that this is a memory that was powerful enough to prompt the narrator to attempt to suppress it. The fear that is associated with going "ice cold" can also be read as a corporeal manifestation of shame. Importantly and poignantly, Krog manages to convey that her daughter's menstruation is not in and of itself shameful. This is in itself highly significant since women's menstruation has long been constructed as shameful. Johnston-Robledo et al (2007: 26) argue that, in "a patriarchal context within which the male body is considered normative, reproductive functions that separated women's bodies from men's were viewed as evidence of women's association with nature and thus their inferiority". They note that a "large literature exists on young women's attitudes towards menstruation, and current studies conclude that women have shameful attitudes towards their periods" (Johnston-Robledo et al., 2007: 26). Menstrual blood serves to "represent an affirmation of womanhood" but it is "also viewed as disgusting and therefore shameful" (Johnston-Robledo et al., 2007: 27). Krog writes back to these negative constructions of menstruation by representing it as an empowering rite of passage in her daughter's life. Even as she does so, however, she is aware of the shaming gaze or ear of the policeman. Her description of him as a "hairy police ear" can be read as a subversive reversal of the traditional construction of women as disembodied parts with female sexuality that is relegated to the realm of nature and animals. Notwithstanding this, she cannot ignore that fact that he is listening to their 
conversation and she shames herself as a mother for her inability to do so to such an extent that she describes it as an "inadequacy" that "haunted" her for the rest of her days. These are powerful assertions that speak to the heart of a central aspect of her identity, namely her role as a mother. Being a wife and a mother continue to be regarded as crucial parts of any woman's identity and Krog's narrator has been shamed for her supposed failures to live up to the idealised versions of both. In the case of her role as a wife, she has been shamed by others who impugn her sexuality and, as a mother, she shames herself. Although there is no indication that her daughter regards the onset of her menses as shameful, the mother cannot but be aware of the historical shaming of women's menstruation and she knows that it is through this prism that the conversation is being overheard. Here we have an excellent illustration of the powerful, selfperpetuating dynamics of shame. There is a sense that the mother is experiencing what researchers have described as shame about feeling ashamed. In her path breaking study, Prosbyn (2005: xiii) "seeks to investigate why it is considered shaming to admit to shame".

It is also significant that, while the term shame is not mentioned in this extract, the feelings of the narrator manifests in her body that turns cold and becomes paralysed like stone. The corporal expression of difficult emotions is a trope that was also important in Country of my Skull. In both these important South African texts, Krog exposes the extent to which shame shapes the ways in which women deal with physical and systemic violence. Her texts also illustrate how these engagements are fundamentally gendered and a close feminist reading reveals that women's narratives are thus constructed in very specific ways. By considering the role of the gendered dynamics of shame in the construction of these narratives, this paper has shed new light on two canonical South African literary works.

\section{References}

Davidoff, Frank. 2002. "Shame: The Elephant in the Room.” British Medical Journal 324: 623-624.

Johnston-Robledo, Ingrid, Sheffield, Kristin, Voigt, Jacqueline and Wilcox-Constantine, Jennifer. 2007. "Reproductive shame: Self-objectification and young women's attitudes towards their reproductive functioning". Women \& Health 46(1): 25-39.

Krog, Antjie. 1998. Country of My Skull. London: Jonathan Cape.

Krog, Antjie. 2009. Begging to be Black. Cape Town: Random House.

Mitchell, Kaye. 2012. "Cleaving to the Scene of Shame: Stigmatized Childhoods in The End of Alice and Two Girls, Fat and Thin”. Contemporary Women's Writing 7(3): 1-19.

Norberg, Cathrine. 2012. "Male and female shame: A corpus-based study of emotion". Corpora 7(2): 159185. 
Probyn, Elspeth. 2005. Blush: Faces of Shame. Minneapolis: University of Minnesota Press. 